\title{
The Development of the Five-Gotra Theory in the Yogācāra School:
}

In Accordance with the Sütra Commentaries

\author{
OKADA Eisaku
}

\section{Introduction}

By employing the term gotra, the Yogācāra school discusses the topics such as the possibility of reaching parinirvanna and the types of enlightenment (bodhi). The Faxiang zong, founded by Xuanzang 玄然, enumerated five gotras, that is, śrāvaka-gotra, pratyekabuddha-gotra, bodhisattva-gotra (or, according to the Yogācārabhümi, bodhisattvagotra is also called tathāgata-gotra, buddha-gotra, mahāyāna-gotra), aniyata-gotra, and agotra, and established the so-called wuxing gebie 五姓各別 theory. Sakuma [2007] has investigated the origins of the wuxing gebie theory in Indian Buddhist texts. His investigation revealed that the five-gotra theory is found in the Sūtrālamkāra-vrttibhāșya attributed to Sthiramati, and based on this finding he argued that the Yogācāra school did not particularly pay attention to this theory. However, except for some commentaries on the Mahāyānasütrālaṃaara, he did not investigate those Indian Buddhist texts which exist only in Tibetan translation.

This paper focuses on the Sütra commentaries of the Yogācāra school which exist only in Tibetan translation namely, Asanga's Buddhānusmrti-vrtti, Vasubandhu's Buddhānusmrtitịikāa, and especially the Āryākșayamatinirdeśa-tịkā attributed to some Yogācāra master who lived after Sthiramati. By examining the five-gotra theory described in these commentaries, I argue that the Yogācāra school did pay attention to the five-gotra theory and developed it.

\section{The Buddhānusmrti-vrtti and the Buddhānusmrti-țikā}

Before examinationing the development of the five-gotra theory in the Yogācāra school, 
in this section I briefly explain how this theory was established. ${ }^{1)}$ The Buddhänusmrtivrtti of Asanga and the Buddhānusmrti-țikā of Vasubandhu are particularly important in this context.

Concerning the object of Buddhist training (vineya), ${ }^{2)}$ the Buddhannusmrti-vrtti comments that a person who does not possess any qualification (skal ba dan mi ldan pa, *abhavya) is a person who possesses the indeterminate gotra (rigs ma nges pa, *aniyatagotra), and a person who possesses a qualification (skal ba dan ldan pa, *bhavya) is a person who possesses one of the gotras within the three vehicles. His commentary also mentions Buddhist training for a person who possesses the indeterminate gotra. ${ }^{3)}$ Therefore, Asanga maintains four types of gotra, and he does not discuss a person who does not possess any gotra. In contrast, the Buddhānusmrtititika comments that a person who does not possess any qualification is a person who does not possess any gotra (rigs med pa, *a-gotra). The rest of his commententary is almost the same as the Buddhānusmrti-vrttii. ${ }^{4)}$ Therefore, Vasubandhu maintains five types of gotras.

According to both commentaries, we can trace the origin of the five-gotra theory in the context of the object of Buddhist training in the Buddhānusmrtti-tịka of Vasubandhu, which he developed based on Asanga.

\section{The Āryākșayamatinirdeśa-țikā}

The Āryākșayamatinirdeśa-tịkā is written from the viewpoint of the Yogācāra school and it cites many texts of this school. As Braarvig [1993: II, lcxvii-cxxx] has pointed out, this commentary quotes not only from Vasubandhu's works but also from Sthiramati's works. Consequently, this text is attributed to some Yogācāra master after Sthiramati. In this commentary, the description of the five-gotra theory is as follows:

ANT (Tib.) D 111a2-5, P 135b1-6:

ṅes pa dań ma nes pa źes bya ba la sogs pa la rigs rnam ${ }_{(\mathrm{P} 13562)}$ pa lńa ste / ñan thos kyi rigs can dan /i) rań sańs rgyas kyi rigs can dan / theg pa chen po'i rigs can dań / rigs ma nes pa dan / rigs med pa'o //

de la rigs med pa'i gan ${ }_{(D) 111 a 3)} Z a g_{(P ~ 13563)}$ rnams ni nes pa ste / de dag tu thams cad duii) 'khor bar gnas par gdon mi za ba'i phyir ro // theg pa gsum du nes pa'i rigs can ni ma nes pa ste / dge ba'i bśes gñen gyi rkyen gyis mya ${ }_{(\mathrm{P} 13564)}$ ñan las 'das par yan 'gyur bas na khams gsum du gnas par nes $\mathrm{pa}_{(\mathrm{D} 111 \mathrm{a})}$ med pa'i phyir ro //

yan na rigs can rnam pa gsum ni nes pa ste / ran ran gi theg pa la brten nas ${ }_{(\mathrm{P} 13565)}$ 'bras bu thob 
par gdon mi za ba'i phyir ro // ma nes pa'i rigs can ni ma nes pa ste / dge ba'i bśes gñen gyi rkyen gyis theg pa gar btsud par 'jug cin / dge ${ }_{(D \text { 111as) }}$ ba'i bśes gñen ${ }_{(P \text { 13566) }}$ dan ma phrad na / mya nan las 'das par 'gyur bar chadiii) pa med pa'i phyir ro //

i) om. $P$, ii) om. $P$, iii) tshad $P$

Regarding those who are is determined, those who are not determined ("niyatâniyata), and so on, the gotra is of five kinds, [namely,] a person who possesses the gotra of the srāvaka, the gotra of the pratyekabuddha, the gotra of the mahāyanna, the indeterminate gotra, and a person who does not possess any gotra.

In these [five gotras], persons who do not possess any gotra are determined. This is because, in all cases, they are determined to stay in samsāra. A person who possesses [one of] the determinate gotras within the three vehicles is undetermined. This is because he will also reach nirvāna by virtue of a good friend, therefore he is undetermined whether he stays in three realms or not.

Moreover, a person who possesses [one of] three kinds of gotras is determined. This is because he is determined to attain a particular result based on each vehicle. A person who possesses the indeterminate gotra is undetermined. This is because even though he is led to one of the vehicles by virtue of a good friend and is initiated into the vehicle, if he does not meet a good friend, there is no destruction at reaching nirvāna.

Thus, the Āryākșayamatinirdeśa-tịka comments that the gotra is of five kinds. Regarding the topic (nes pa dan ma nes pa, ${ }^{*}$ niyatâniyata), this commentary first refers to a person who does not possess any gotra and a person who possesses one of the gotras within the three vehicles. Then the commentator mentions a person who possesses one of the gotras within the three vehicles and a person who possesses the indeterminate gotra. The difference in these perspectives is what is meant by "determinate" (nes pa, *niyata), which is the topic of this commentry. Futhermore, since this commentary mentions five gotras in another place, ${ }^{5)}$ it can be said that this commentary maintains five types of gotras. This suggests that the five-gotra theory in the Yogācāra school was developed even after Vasubandhu and Sthiramati.

\section{Conclusion}

The five-gotra theory is established in the lineage from Asanga to Vasubandhu, and as the previous study has pointed out, this theory is found in the work attributed to Sthiramati. Through the examination of the description of the five-gotra theory in the Sütra commentaries, this paper clarifies that the description of the five-gotra theory is also found in the Âryāksayamatinirdeśa-tịkā, and that this theory was developed in the 
Yogācāra school after Vasubandhu and Sthiramati.

\section{Notes}

1) Detailed contents concerning the establishment of the five-gotra theory in Yogāaāra school are expected to be published this year (2016) in the Mikkyō bunka 密教文化 [Journal of esoteric Buddhism] 235 or 236.

2) See Okada [2013] [2014] for the relationship between the object of Buddhist training and the concept of gotra.

3) BuAV (Tib.) D 14a5-b1, P 17a3-7, (Jpn. trans.) Nakamikado [2010: 77].

4) BuAT (Tib.) D 58a1-3, P 72a8-b4, (Jpn. trans.) Nakamikado [2008: 124].

5) ANT (Tib.) D 145a5-6, P 177b4-5.

\section{Primary Literatures and Abbreviations}

ANȚ Āryākșayamatinirdeśa-țikā. (Tib.) D (no. 3994) ci 1a1-269a7, P [vol. 104] (no. 5495) ci 1a1$343 a 7$.

BuAT Buddhānusmrti-țikā of Vasubandhu. (Tib.) D (no. 3987) ngi 55b3-63b5, P [vol. 104] (no. 5487) ngi 69a6-79b8.

BuAV Buddhānusmṛti-vṛtti of Asańga. (Tib.) D (no. 3982) ngi 11b5-15a6, P [vol. 104] (no. 5482) ngi 14a1-18b1.

Tib. Tibetan translation.

\section{Secondary Literatures}

Braarvig, Jens. 1993. Akșayamatinirdeśasūtra. 2 vols. Oslo: Solum Forlag.

Nakamikado Keikyō 中御門敬教. 2008. “Seshin saku Butsuzuinen kōchū wayaku kenkyū: Zenhan bubun, butsu jūgō ni motozuku sanjō kyōtsū no nenbutsu-kan" 世親作『仏随念広註』和訳研 究: 前半部分・仏十号に基づく三乗共通の念仏観. Bukkō Daigaku sōgō kenkyū kiyō 佛教大学総 合研究紀要 15: 105-130.

—. 2010. “Mujaku saku Butsuzuinen chū to Hōzuinen chū wayaku kenkyū" 無着作『仏随念註』

と『法随念註』和訳研究. Bukkō Daigaku sōgō kenkyū kiyō 佛教大学総合研究紀要 17: 67-92.

Okada Eisaku. 2013. "Agotrastha in the Bodhisattvabhümi: The Paripäkapatala and the Bodhisattvagunapatala." Indogaku Bukkyōgaku kenkyū 印度学仏教学研究 61 (3): 1204-1208.

- 2014. "Buddhist Training of Living Beings by the Bodhisattva in the Bodhisattvabhumi: Focusing on the Salvation of the Agotrastha." Indogaku Bukkyōgaku kenkyū 印度学仏教学研究 62 (3): $1243-1247$.

Sakuma Hidenori 佐久間秀範. 2007. “Goshō kakubetsu no genryū o tazunete” 五姓格別の源流を 訪ねて. In Katō Seiichi hakase koki kinen ronbunshū: Shingon mikkyō to Nihon bunka, gekan 加藤精 一博士古稀記念論文集: 真言密教と日本文化,下巻, 265-305. Tokyo: Nonburusha.

(This work was supported in part by a Grant-in-Aid for Scientific Research from Mishima Kaiun 
Memorial Foundation.)

Key words five-gotra, Āryākșayamatinirdeśațikā, Buddhānusmrtițikā, Buddhānusmṛtivrttti, Yogācāra (Part-time Lecturer, Kyoto University, Entrusted Researcher of the Institute of Esoteric Buddhist Culture, Koyasan University)

- New Publication

BDK Tripițaka Translation Series

The Collection for the Propagation and Clarification of Buddhism

Volume I

（弘明集 卷一〜七）

Translated by Harumi Hirano Ziegler

$15.6 \times 23.1 \mathrm{~cm}, 360$ pp., $¥ 6,480(\$ 60)$

Bukkyo Dendo Kyokai, 2015

(Society for the Promotion of Buddhism) 